Article

\title{
Rusty Blackbird (Euphagus carolinus) Foraging Habitat and Prey Availability in New England: Implications for Conservation of a Declining Boreal Bird Species
}

\author{
Amanda Pachomski ${ }^{1, *}$, Stacy McNulty ${ }^{2, * \mathbb{D}}$, Carol Foss $^{3}$, Jonathan Cohen ${ }^{1}$ and Shannon Farrell ${ }^{1}$ \\ 1 Department of Environmental and Forest Biology, State University of New York College of Environmental \\ Science and Forestry, 1 Forestry Drive, Syracuse, NY 13210, USA; jcohen14@esf.edu (J.C.); \\ sfarrell@esf.edu (S.F.) \\ 2 Adirondack Ecological Center, State University of New York College of Environmental Science and Forestry, \\ 6312 State Route 28N, Newcomb, NY 12852, USA \\ 3 New Hampshire Audubon Society, 84 Silk Farm Road, Concord, NH 03301, USA; cfoss@nhaudubon.org \\ * Correspondence: amandapachomski@gmail.com (A.P.); smcnulty@esf.edu (S.M.)
}

check for updates

Citation: Pachomski, A.; McNulty, S.; Foss, C.; Cohen, J.; Farrell, S. Rusty Blackbird (Euphagus carolinus) Foraging Habitat and Prey Availability in New England: Implications for Conservation of a Declining Boreal Bird Species. Diversity 2021, 13, 99. https:// doi.org/10.3390/d13020099

Academic Editor: Michael Wink

Received: 31 December 2020

Accepted: 18 February 2021

Published: 23 February 2021

Publisher's Note: MDPI stays neutral with regard to jurisdictional claims in published maps and institutional affiliations.

Copyright: (c) 2021 by the authors. Licensee MDPI, Basel, Switzerland. This article is an open access article distributed under the terms and conditions of the Creative Commons Attribution (CC BY) license (https:// creativecommons.org/licenses/by/ $4.0 /)$.

\begin{abstract}
The Rusty Blackbird (Euphagus carolinus) is an imperiled migratory songbird that breeds in and near the boreal wetlands of North America. Our objective was to investigate factors associated with Rusty Blackbird wetland use, including aquatic invertebrate prey and landscape features, to better understand the birds' habitat use. Using single-season occupancy modeling, we assessed breeding Rusty Blackbird use of both active and inactive beaver-influenced wetlands in New Hampshire and Maine, USA. We conducted timed, unlimited-radius point counts of Rusty Blackbirds at 60 sites from May to July 2014. Following each point count, we sampled aquatic invertebrates and surveyed habitat characteristics including percent mud cover, puddle presence/absence, and current beaver activity. We calculated wetland size using aerial imagery and calculated percent conifer cover within a $500 \mathrm{~m}$ buffer of each site using the National Land Cover Database 2011. Percent mud cover and invertebrate abundance best predicted Rusty Blackbird use of wetlands. Rusty Blackbirds were more likely to be found in sites with lower percent mud cover and higher aquatic invertebrate abundance. Sites with Rusty Blackbird detections had significantly higher abundances of known or likely prey items in the orders Amphipoda, Coleoptera, Diptera, Odonata, and Trichoptera. The probability of Rusty Blackbird detection was $0.589 \pm 0.06$ SE. This study provides new information that will inform habitat conservation for this imperiled species in a beaver-influenced landscape.
\end{abstract}

Keywords: Rusty Blackbird; Euphagus carolinus; boreal wetlands; aquatic macroinvertebrates; foraging ecology; occupancy modeling

\section{Introduction}

The Rusty Blackbird (Euphagus carolinus) is a migratory songbird that breeds in and near wetlands of the boreal forests of Canada and Alaska as well as in the northern regions of New York and the Acadian Forest (New England and the Canadian Maritime Provinces). The Rusty Blackbird is representative of global boreal avian species declines and has experienced the worst population loss of thirteen boreal-breeding species [1,2]. Although the Rusty Blackbird was once common, the species has declined by an estimated $90 \%$ since the 1960s [3]. The species was estimated to have declined by $5.1 \%$ per year from over 13 million birds in 1965-1966 to roughly 2 million birds in 2002-03 based on modeling from standardized winter counts [1]. Furthermore, the southeastern limits of the bird's breeding range appear to have retreated northward coincident with the population decline [4]. The US Fish and Wildlife Service has listed the Rusty Blackbird as a Focal Species of Birds of Management Concern [5]; the IUCN Red List considers the species to be Vulnerable [6]. The cause of the Rusty Blackbird's decline is not fully understood; climate change [4], mercury 
contamination [7], hematozoa infections [8], timber harvesting on breeding grounds [9], and winter habitat loss [10] have been suggested as possible factors.

As with all species, suitable foraging and nesting habitat are key components for Rusty Blackbird persistence. In New England, Rusty Blackbirds select nest sites with minimal canopy cover, high basal area of young conifers $(<1.5 \mathrm{~m}$ height $)[9,11]$, and patches of forest adjacent to open areas, including wetlands [11]. They build cup nests in live trees, usually red spruce (Picea rubens), black spruce (Picea mariana), or balsam fir (Abies balsamea), surrounded by other young conifers, and occasionally in speckled alder (Alnus incana) swamps, in snags, or in isolated conifers in open areas [11]. Rusty Blackbird habitat can be created or improved by forest management or natural disturbance, especially by the American beaver (Castor canadensis). The beaver, an ecosystem engineer, creates impoundments of water by damming streams [12], forming wetlands utilized by a diversity of wildlife species. Because deciduous trees and shrubs are a preferred food of the beaver [13], they selectively harvest several woody species in proximity to their impoundments, thereby increasing the percent cover of conifers [14], which is desirable for Rusty Blackbird nesting. Beavers have a long-lasting impact on the landscape; by digging channels and creating dams, beavers increase both the depth and area of wetlands [15]. Individual beaver ponds may be active for one to many years at a time as the animals move to find new sources of food, resulting in a matrix of different-aged ponds, meadows, and streams in a wetland complex [16]. Beavers increase the diversity of and shift the macroinvertebrate assemblage $[17,18]$ as well as increase macroinvertebrate abundance [18] within impounded wetlands and streams. Thus, beavers may create an ideal habitat for Rusty Blackbirds, with flooded, macroinvertebrate-rich wetlands for foraging and clumps of nearby conifers for nesting.

It is critical to monitor Rusty Blackbird populations and habitat use in order to make and evaluate the result of management decisions. Previous research within the Rusty Blackbird's breeding range has focused on demography, nesting ecology, and possible causes of decline. Information about the species' diet and foraging site preferences are scant. Rusty Blackbirds are more insectivorous than other Icterids, based on their skull and bill anatomy [19] and analysis of stomach contents [19-22]. They forage aerially, from perches, and while walking along the water's edge. A breeding Rusty Blackbird diet consists mostly of aquatic macroinvertebrates, such as beetle adults and larvae [22,23], Odonate (dragonfly and damselfly) larvae [24], Trichoptera (caddisfly) larvae and emergent adults [25], and Tipulid (crane fly) larvae [25], but they also hunt aerial prey such as mosquitoes [26]. Breeding Rusty Blackbirds also forage for a variety of terrestrial and volant invertebrates, including snails [27], grasshoppers [20], caterpillars [20], spiders [20,27,28], adult dragonflies [25,29], adult mayflies [29], ants, centipedes, and crustaceans [22]. Furthermore, although Rusty Blackbirds are mostly insectivorous during the breeding season [30], the species has been known to eat some vertebrates such as small fish [27,28] and salamanders [27]. In addition to consumption of various prey items during the breeding season, Rusty Blackbirds exhibit diet plasticity by switching to a more generalized diet of seeds, fruit, acorns, grains, and insects during autumn and winter [22,23]. Overall, summer feeding observations and stomach specimens are very limited in number, and little is known about their foraging habitat requirements. Understanding wetland prey availability during the breeding season in key patches will enable scientists and land managers to identify high-quality foraging sites and may eventually suggest mechanisms behind the Rusty Blackbird decline and potential for recovery.

Rusty Blackbirds are rare and difficult to detect, especially within their remote and hard-to-access breeding grounds; thus, traditional, short duration (five or ten minutes) avian point-counts are not sufficient for accurately detecting breeding Rusty Blackbirds [3]. We used a single-season site occupancy modeling approach [31] to account for imperfect detection and model Rusty Blackbird use of 60 wetland sites as a function of habitat covariates, with a focus on foraging habitat and food availability. We chose multiple a priori habitat covariates that we expected to be biologically important for Rusty Blackbirds 
based on previous studies and our own experience. We hypothesized that the probability of Rusty Blackbird wetland use: (1) increases with current beaver activity, (2) increases with the presence of puddles, and (3) increases with increasing conifer cover. We hypothesized that the probability of detecting a present Rusty Blackbird (1) is not affected by the time of day during daylight hours, (2) decreases with increasing wind speed, (3) is highest during the chick-rearing period, and (4) decreases with increasing wetland size. This study is the first to assess Rusty Blackbird foraging habitat use in New England and the first to include prey availability as a covariate in Rusty Blackbird occupancy modeling.

\section{Materials and Methods}

\subsection{Study Area}

We surveyed breeding Rusty Blackbird use of both active and inactive beaver- influenced wetlands in Coos County, New Hampshire, and Oxford County, Maine (Figure 1). Sites were located either on federal land at Umbagog National Wildlife Refuge (44.832344, -71.075496) or were privately owned and managed by Wagner Forest Management, Ltd. The study area has a mean precipitation of $102.9 \mathrm{~cm}$ per year, a mean annual high temperature of $11.67^{\circ} \mathrm{C}$, and a mean low temperature of $-2.22^{\circ} \mathrm{C}$ (measured in Colebrook, $\mathrm{NH}$ [ [32]. The mean elevation of surveyed wetlands was $473.3 \mathrm{~m}$ (range $=110 \mathrm{~m}$ to $780 \mathrm{~m}$ ). Beavers have been modifying wetland hydrology and upland vegetation in the region for decades; survey sites were categorized as either active (impounded/modified in the past year and hosting a resident beaver colony) or inactive (previously impounded, but not currently occupied by beavers) wetlands. The forests in this remote area of New England are extensively managed, with active logging operations occurring near most of our study sites.

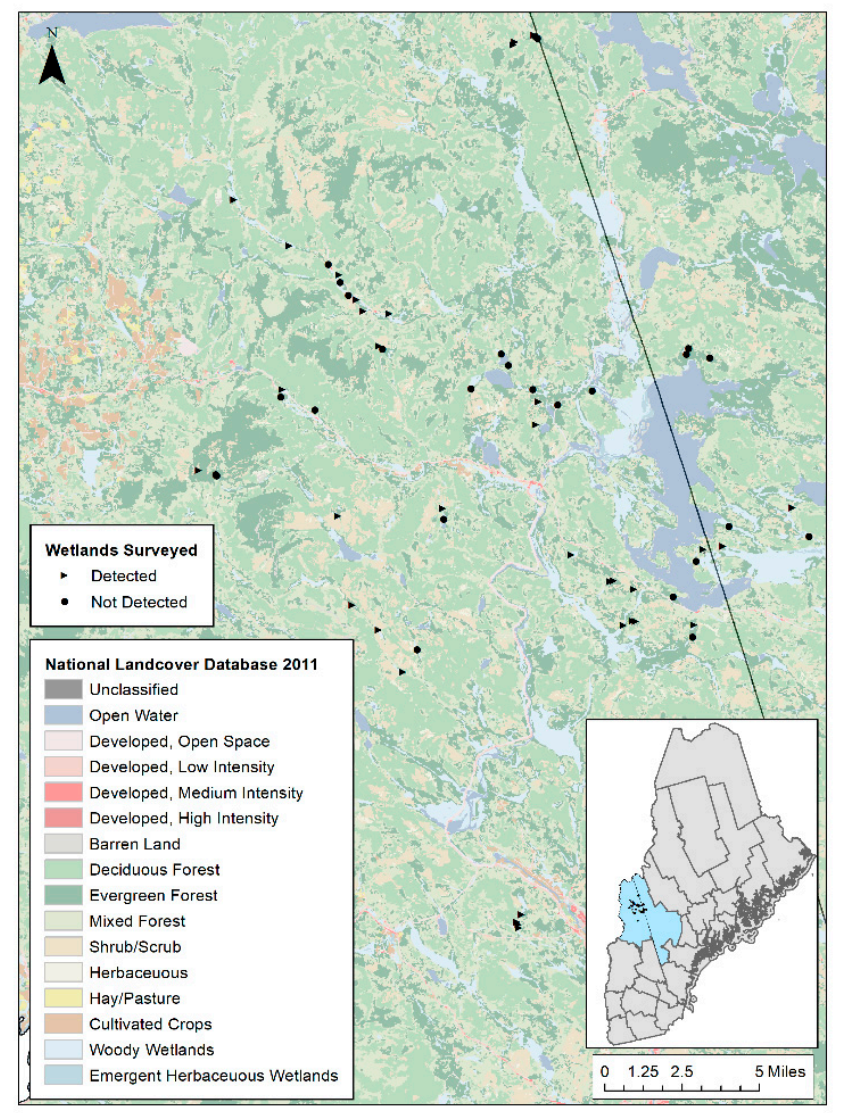

Figure 1. Land cover classes of the study area and digitized polygons of wetlands where Rusty Blackbirds were detected (black triangles) or were not detected (black circles) in northern New England, USA, with $500 \mathrm{~m}$ buffer circles showing habitat in 2014. 


\subsection{Methods}

To evaluate Rusty Blackbirds' use of wetlands, we conducted timed, 30 min long, unlimited-radius point counts at 60 sites in 2014 within a $25 \mathrm{~km}$ radius of the town center of Errol, NH. We selected count locations from a pool of 263 discrete (e.g., above a dam) beaver-influenced impoundments within $500 \mathrm{~m}$ of a road, which we identified using satellite imagery and expert knowledge of the study area. We used ArcMap to randomly select 39 wetland sites and then systemically selected 21 additional, nearby wetlands to maximize our sample size. Bird surveys were conducted from a fixed, marked point located at the southern edge of each wetland. Some sites were located relatively close together (100-300 m apart), so to avoid double counting, pairs of observers concurrently surveyed adjacent sites, cross-checked the timing of field observations field post-survey, and excluded possible double counts of birds. Due to time and logistical constraints, we surveyed sites in pairs based on their spatial proximity; thus, sites were not randomly visited.

We surveyed each point three times, once during each of three two-week intervals (14 May to 27 May, 28 May to 10 June, and 11 June to 24 June 2014). Due to site access restrictions, two of the 60 sites were only surveyed twice. We timed the survey intervals to align with Rusty Blackbird incubation, nestling rearing, and fledging stages of the breeding season because we suspected that detectability would vary based on the birds' nesting behavior.

We conducted surveys between 8:00 and 18:00. We chose not to limit our surveys to early morning hours in order to maximize our sample size and because Rusty Blackbirds are known to sing throughout the day [33]. Through pilot surveys, we found that a point count duration of $30 \mathrm{~min}$ was the most effective yet efficient count duration for detecting Rusty Blackbirds in our study area [33]. During each point count, two independent observers recorded visual and/or auditory detections of Rusty Blackbirds and time to first detection (if detected) without the use of any recorded playback. We also recorded wind speed, temperature, precipitation, and time of day (Table 1).

Table 1. Site and field survey covariates used to model detectability and site occupancy of Rusty Blackbirds in northern New England in 2014; the data collection method was by remote sensing (GIS) or at the site (Field).

\begin{tabular}{ll}
\hline Covariate & Description \\
\hline Beaver & Binary measure of observed beaver activity \\
Day & Ordinal survey date \\
Elevation & Site elevation in meters \\
Water.depth & Average depth (centimeters) of open water near pond edge \\
Invert.abundance & Average number of invertebrate individuals observed in three samples \\
Invert.richness & Total number of invertebrate families observed in three samples \\
Min & Survey start time converted to minute of day \\
Mud & Visual estimate of percent exposed mud within a wetland \\
Open.water & Visual estimate of percent open water within a wetland \\
Pct.conifer & Percent conifer cover within a 500-m buffer of wetland using NLCD 2011 \\
Puddles & Binary measure of puddles observed 0, 1, 2, or 3 times out of three surveys \\
Precip & Binary measure of presence of precipitation during survey \\
Size & Wetland size measured in meters squared \\
Temp & Measure of temperature (Celsius) at the start of the survey \\
Visit & Survey period 1, 2, or 3 Field \\
Wind & Wind speed (km per hour) measured using an anemometer held at $4.5 \mathrm{~m}$ height at the start of the survey \\
Yng.conifer & Binary measure of presence of dense regenerating spruce and/or fir trees $<1.5 \mathrm{~m}$ tall \\
\hline
\end{tabular}

We collected field data on both vegetation and land cover variables, including percent spruce and balsam fir cover around the wetland, percent cover of open water, percent cover of mud, depth of open water, as well as evidence of recent beaver activity (Table 1). We used the perimeter-based cover estimate method [34] to measure the percent exposed mud and percent open water within the wetland during each survey occasion and then averaged the habitat data across the three occasions. 
We collected aquatic invertebrate samples at the point count site (southern edge of each wetland's standing pool of water) with ten sweeps of a D-frame dip net, probing along the water's edge. Macroinvertebrate samples were stored in $70 \%$ ethanol and identified to family when possible, otherwise to order or subclass [35]. We used the macroinvertebrate count as a proxy for abundance of Rusty Blackbird prey within a wetland. We averaged the counts for each of the sites' three invertebrate samples and included this abundance as a site covariate in our wetland use models. We also included the total invertebrate family richness for all of each site's samples. For taxa that we were only able to be identified to subclass or order, such as leeches, we assumed that one family was observed for each subclass or order.

We used ArcMap to calculate wetland size and quantify land cover type as habitat characteristics that might drive Rusty Blackbird foraging site selection. Because Rusty Blackbirds forage within multiple wetland types, we chose not to use a wetland classification system and instead delineated all wetland features within a site as a single polygon, using Google Earth satellite imagery (dated 18 September 2013) and field experience as a guide. We then calculated the area of each wetland polygon and used the National Land Cover Database 2011 (NLCD) [36] to calculate the percent conifer cover within a $500 \mathrm{~m}$ radius of each wetland, which is the approximate size of a typical Rusty Blackbird breeding home range [11]. We recorded the elevation of each wetland survey point in the field using a GPS unit.

\subsection{Analysis}

We used the protocol developed by MacKenzie et al. [31] to model Rusty Blackbird use of wetlands using single-species occupancy modeling based on our detection histories and field and geospatial data (Table 1). Occupancy probability ( $\Psi$ ) and detection probability (p) were modeled as linear functions of covariates using the logit link to constrain predicted values between 0 and 1 . These models assume a closed population between surveys, and where that assumption is violated, $\Psi$ is interpreted as habitat use rather than occupancy. Because Rusty Blackbirds may forage among multiple wetlands within a large area, defining a site as a single wetland, as we did, may violate the assumption of independence of observations. Furthermore, concurrent Rusty Blackbird productivity research revealed that Rusty Blackbirds nested near many of our study sites. However, breeding Rusty Blackbirds in New England have been found to nest up to $400 \mathrm{~m}$ away from wetlands, and fledglings can move over $1 \mathrm{~km}$ away from their nests within a few weeks of fledging [37], so we were not able to assume that site occupancy was constant throughout the study period. Thus, we considered sites with at least one positive Rusty Blackbird detection to be "used" rather than "occupied" [38].

We performed this analysis using Package unmarked [39] in Program R [40]. Our candidate set of models included biologically plausible variables known or thought to affect Rusty Blackbird habitat suitability. We first modeled survey-specific covariates affecting p (date, precipitation, temperature, time, visit, wetland size, and wind) while modeling $\Psi$ as constant. Then, we chose the model with the lowest Akaike Information Criterion (AIC) score as the best-fit detectability model and used its survey covariate(s) in our base $\Psi$ model, following the approach of Powell et al., 2014 [41]. Next, we created a candidate set of models with one or more site covariates (beaver, invertebrate abundance, invertebrate richness, open water, mud, puddles, water depth, percent conifer, young conifer, elevation, and wetland size). We avoided including significantly correlated $(p<0.05)$ covariates (calculated using Spearman Rho and Pearson Chi-Square tests for continuous and categorical covariates, respectively) within the same wetland use models. We used Package AICcmodavg [42] to estimate c-hat, the overdispersion parameter, to adjust for overdispersion as needed, and to assess model fit. We used the MacKenzie and Bailey Goodness-of-fit Test [43] to test the fit of our global wetland use model, which contained all covariates included in our candidate set of models, with 1000 bootstraps. 
To assess whether Rusty Blackbirds select foraging sites based on the abundance of specific aquatic invertebrate prey types, we used the two-sample Poisson rate test to test for a difference between the maximum invertebrate abundance per order at sites with and without Rusty Blackbird detections. We included underrepresented invertebrate groups in abundance totals in order to reflect total prey availability at each site.

\section{Results}

We detected Rusty Blackbirds during 66 of 178 surveys. Our base detectability model (without covariates) yielded a detection probability (p) of $0.589 \pm 0.06 \mathrm{SE}(95 \% \mathrm{CI}:-0.10$, 0.82 ). Detection probability was best predicted by visit (survey period), which was the only covariate in the top model (Table 2). The probability of detection was highest in visit 2 and lowest in visit 1 . Back-transformed parameter estimates on the probability scale for visit yielded $p=0.416 \pm 0.09 \mathrm{SE}$ for visit $1, p=0.765 \pm 0.08 \mathrm{SE}$ for visit 2 , and $p=0.742 \pm 0.09$ SE for visit 3.

Table 2. Model selection for detectability of Rusty Blackbirds in northern New England in 2014.

\begin{tabular}{cccccc}
\hline Model & K $^{\mathbf{a}}$ & AIC $^{\mathbf{b}}$ & AAIC $^{\mathbf{c}}$ & wi $^{\mathbf{d}}$ & -2 Log-Likelihood $^{\text {2 }}$ \\
\hline p(visit) $\Psi()$. & 4 & 214.38 & 0.00 & 0.513 & 206.4 \\
p(size) $\Psi()$. & 3 & 218.18 & 3.80 & 0.077 & 212.2 \\
p(precip) $\Psi()$. & 3 & 219.19 & 4.81 & 0.046 & 213.2 \\
p(temp) $\Psi()$. & 3 & 219.26 & 4.88 & 0.045 & 213.2 \\
p(time) $\Psi()$. & 3 & 219.34 & 4.96 & 0.043 & 213.3 \\
p(day) $\Psi()$. & 3 & 219.39 & 5.01 & 0.042 & 213.4 \\
p(wind) $\Psi()$. & 3 & 219.50 & 5.12 & 0.040 & 213.5 \\
p(day+precip) $\Psi()$. & 4 & 220.87 & 6.49 & 0.020 & 212.9 \\
p(time+precip) $\Psi()$. & 4 & 220.96 & 6.58 & 0.019 & 213.0 \\
p(day+time) $\Psi()$. & 4 & 220.99 & 6.61 & 0.019 & 213.0 \\
p(temp+wind) $\Psi()$. & 4 & 221.05 & 6.67 & 0.018 & 213.1 \\
p(time+temp) $\Psi()$. & 4 & 221.07 & 6.69 & 0.018 & 213.1 \\
p(day+temp) $\Psi()$. & 4 & 221.08 & 6.70 & 0.018 & 213.1 \\
p(time+wind) $\Psi()$. & 4 & 221.19 & 6.81 & 0.017 & 213.2 \\
p(day+wind) $\Psi()$. & 4 & 221.25 & 6.87 & 0.016 & 213.3 \\
p(time2) $\Psi()$. & 4 & 221.32 & 6.94 & 0.016 & 213.3 \\
p(day2) $\Psi()$. & 4 & 221.36 & 6.98 & 0.015 & 212.4 \\
p(temp*wind) $\Psi()$. & 5 & 222.43 & 8.05 & 0.009 & 212.9 \\
p(time+precip+wind) $\Psi()$. & 5 & 222.90 & 8.52 & 0.007 & \\
\hline
\end{tabular}

a Number of parameters; ${ }^{\mathrm{b}}$ Akaike's Information Criterion; ${ }^{\mathrm{c}}$ Difference in the model's AIC from that of the top model; ${ }^{\mathrm{d}}$ Akaike weight. (.) Indicates that the parameter $\Psi$ was held constant.

We detected Rusty Blackbirds at 35 out of 60 sites. Based on the null occupancy model without site covariates, Rusty Blackbirds used $0.629 \pm 0.07 \mathrm{SE}$ of the study sites. With $\alpha=0.05$ and a c-hat value of less than 3 , we concluded that our global wetland model had an acceptable fit [44]. However, because a c-hat value greater than 1 suggests overdispersion, we adjusted standard error estimates for each wetland use model by a factor of c-hat [44] and ranked models based on Quasi Akaike's Information Criterion (QAIC) scores.

The top model (number of parameters $\mathrm{k}=7,-2$ log-likelihood $=188.231$, QAIC $=$ 123.4366), included the survey covariate "visit" in the detection probability linear predictor and the site covariates "invertebrate abundance" and "mud" in the occupancy linear predictor (Table 3). Rusty Blackbirds preferred sites with higher aquatic invertebrate abundance (Figure 2a) and lower percent mud cover (Figure 2b). This model accounted for over $60 \%$ of the adjusted model weight. Because the second model was not within four delta QAIC units of the top model, we did not model average parameter estimates across all of the models included in the candidate set of wetland use models [45]. 


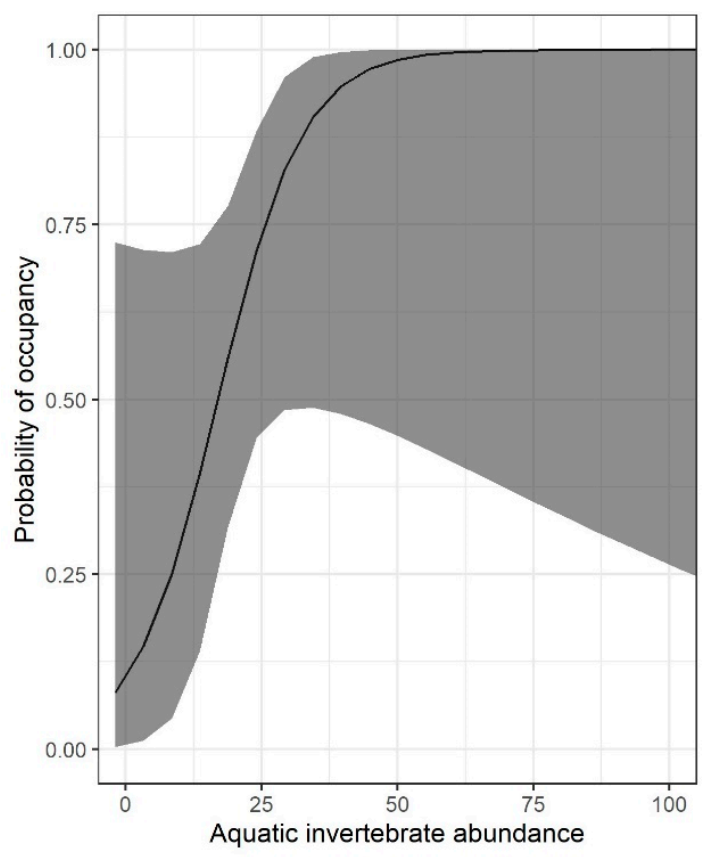

(a)

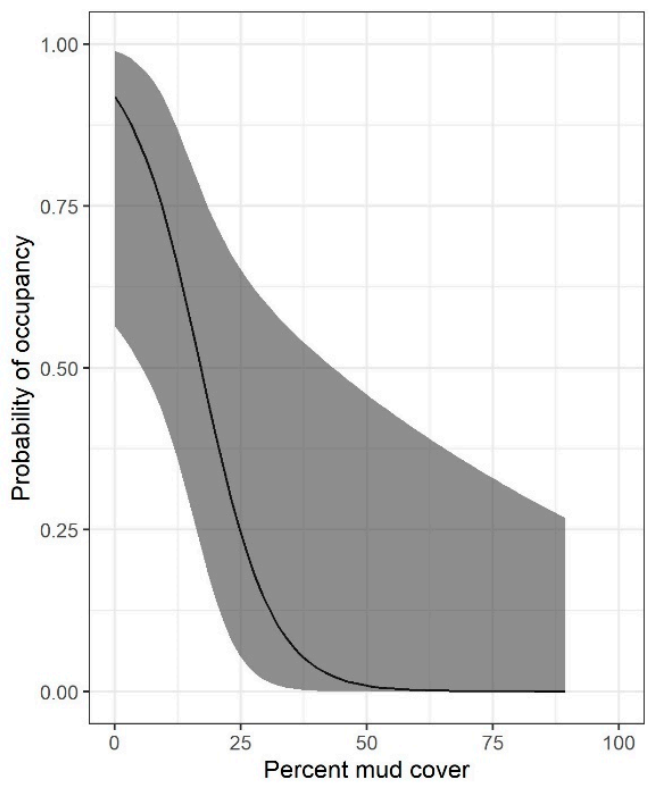

(b)

Figure 2. Relationship between probability of Rusty Blackbird occupancy and site covariates, percent cover of aquatic invertebrate abundance (a) and mud (b), with $95 \%$ confidence bands.

Aquatic invertebrate richness (across all taxa) was not a predictor of Rusty Blackbird wetland use. However, it is worth noting the extent to which each taxon varied in abundance across our study sites as well as the difference (or lack thereof) between taxa at sites with and without Rusty Blackbird detections. Survey sites had a mean of 6.92 insect families $( \pm 0.37 \mathrm{SE}$; range $=1$ to 14$)$ and a mean invertebrate count of 49.98 specimens $( \pm 6.70 \mathrm{SE}$; range $=6$ to 205.5) combined from three samples in 2014. Sites with Rusty Blackbird detections had higher maximum invertebrate abundance of Amphipoda $(p<0.001)$, Coleoptera $(p=0.002)$, Collembola $(p<0.001)$, Diptera $(p<0.001)$, Hemiptera $(p=0.018)$, Odonata $(p<0.001)$, Oligochaeta $(p=0.013)$, Plecoptera $(p=0.004)$, and Trichoptera $(p=0.033)$ than did sites with no detections (Table 4). 
Table 3. Model selection for wetland use of Rusty Blackbirds in northern New England in 2014, using site occupancy analysis with AIC scores adjusted for overdispersion (c-hat =1.78).

\begin{tabular}{|c|c|c|c|c|c|}
\hline Model & $\mathbf{K}^{\mathbf{a}}$ & QAIC $^{b}$ & $\Delta \mathrm{QAIC}^{\mathrm{c}}$ & $Q w_{i}{ }^{d}$ & -2 Log-Likelihood \\
\hline $\mathrm{p}$ (visit) $\Psi$ (invert.abundance + mud) & 7 & 123.44 & 0.00 & 0.600 & 188.2 \\
\hline $\mathrm{p}$ (visit) $\Psi$ (mud) & 6 & 128.06 & 4.63 & 0.060 & 199.6 \\
\hline $\mathrm{p}$ (visit) $\Psi$ (invert.abundance) & 6 & 128.31 & 4.87 & 0.053 & 200.0 \\
\hline $\mathrm{p}$ (visit) $\Psi$ (invert.abundance+yng.conifer) & 7 & 129.87 & 6.43 & 0.024 & 199.3 \\
\hline $\mathrm{p}$ (visit) $\Psi()$. & 5 & 129.99 & 6.55 & 0.023 & 206.4 \\
\hline $\mathrm{p}$ (visit) $\Psi$ (mud+yng.conifer) & 7 & 130.05 & 6.61 & 0.022 & 199.6 \\
\hline $\mathrm{p}$ (visit) $\Psi$ (beaver+invert.abundance) & 7 & 130.12 & 6.69 & 0.021 & 199.7 \\
\hline $\mathrm{p}(.) \Psi()$. & 3 & 130.21 & 6.77 & 0.020 & 213.6 \\
\hline $\mathrm{p}$ (visit) $\Psi$ (invert.abundance+pct.conifer) & 7 & 130.35 & 6.92 & 0.019 & 200.1 \\
\hline $\mathrm{p}$ (visit) $\Psi$ (invert.richness) & 6 & 130.73 & 7.29 & 0.016 & 204.2 \\
\hline $\mathrm{p}$ (visit) $\Psi$ (open.water) & 6 & 130.94 & 7.51 & 0.014 & 204.6 \\
\hline $\mathrm{p}$ (visit) $\Psi$ (pct.conifer) & 6 & 131.07 & 7.63 & 0.013 & 204.8 \\
\hline $\mathrm{p}$ (visit) $\Psi$ (yng.sof+beaver+invert.abundance) & 8 & 131.58 & 8.14 & 0.010 & 198.8 \\
\hline $\mathrm{p}$ (visit) $\Psi$ (yng.conifer) & 6 & 131.91 & 8.47 & 0.009 & 206.2 \\
\hline $\mathrm{p}$ (visit) $\Psi$ (puddles $3 \mathrm{x})$ & 6 & 131.92 & 8.49 & 0.009 & 206.3 \\
\hline $\mathrm{p}$ (visit) $\Psi$ (elevation) & 6 & 131.93 & 8.49 & 0.009 & 206.3 \\
\hline $\mathrm{p}$ (visit) $\Psi($ size $)$ & 6 & 131.97 & 8.53 & 0.008 & 206.3 \\
\hline p(visit) $\Psi$ (water.depth) & 6 & 131.97 & 8.53 & 0.008 & 206.4 \\
\hline $\mathrm{p}$ (visit) $\Psi$ (beaver) & 6 & 131.99 & 8.55 & 0.008 & 206.4 \\
\hline $\mathrm{p}$ (visit) $\Psi$ (invert.richness+yng.conifer) & 7 & 132.68 & 9.24 & 0.006 & 204.1 \\
\hline $\mathrm{p}$ (visit) $\Psi$ (beaver+invert.richness) & 7 & 132.73 & 9.29 & 0.006 & 204.2 \\
\hline $\mathrm{p}$ (visit) $\Psi$ (open.water+pct.conifer) & 7 & 132.91 & 9.48 & 0.005 & 204.5 \\
\hline $\mathrm{p}$ (visit) $\Psi$ (pct.conifer+puddles.3x) & 7 & 132.97 & 9.53 & 0.005 & 204.6 \\
\hline $\mathrm{p}$ (visit) $\Psi$ (pct.conifer+beaver) & 7 & 133.05 & 9.61 & 0.005 & 204.8 \\
\hline p(visit) $\Psi$ (yng.conifer) & 7 & 133.84 & 10.41 & 0.003 & 206.1 \\
\hline $\mathrm{p}$ (visit) $\Psi$ (size+yng.conifer) & 7 & 133.86 & 10.43 & 0.003 & 206.1 \\
\hline p(visit) $\Psi$ (water.depth+yng.conifer) & 7 & 133.89 & 10.46 & 0.003 & 206.2 \\
\hline p(visit) $\Psi$ (yng.conifer+beaver) & 7 & 133.90 & 10.46 & 0.003 & 206.2 \\
\hline p(visit) $\Psi$ (water.depth+size) & 7 & 133.95 & 10.52 & 0.003 & 206.3 \\
\hline $\mathrm{p}$ (visit) $\Psi$ (beaver+size) & 7 & 133.96 & 10.53 & 0.003 & 206.3 \\
\hline $\mathrm{p}$ (visit) $\Psi$ (pct.conifer+beaver+puddles.3x) & 8 & 134.97 & 11.53 & 0.002 & 204.6 \\
\hline
\end{tabular}

${ }^{a}$ Number of parameters. ${ }^{b}$ Quasi Akaike's Information Criterion. ${ }^{c}$ Difference in the model's QAIC from that of the top model. ${ }^{\mathrm{d}}$ Quasi Akaike weight.

Table 4. Summary statistics and results of a 2-sample Poisson rate test for differences between maximum invertebrate specimen abundance per survey per order from three aquatic macroinvertebrate surveys per site for sites with and without Rusty Blackbird (RUBL) detections in northern New England in 2014.

\begin{tabular}{|c|c|c|c|c|c|c|c|c|c|c|}
\hline \multirow[b]{2}{*}{ Order } & \multicolumn{3}{|c|}{ RUBL Used $^{a}$} & \multicolumn{3}{|c|}{ RUBL Undetected $^{\mathbf{b}}$} & \multicolumn{3}{|c|}{ Poisson Estimates } & \multirow[b]{2}{*}{$p$-Value ${ }^{\mathrm{d}}$} \\
\hline & $\begin{array}{l}\text { Max } \\
\text { Count }\end{array}$ & $N$ & Mean & $\begin{array}{l}\text { Max } \\
\text { Count }\end{array}$ & $N$ & Mean & $\begin{array}{l}\text { Estimate for } \\
\text { Difference }^{c}\end{array}$ & $\begin{array}{l}95 \% \text { Lower } \\
\text { Bound }\end{array}$ & $\mathbf{Z}$ & \\
\hline Amphipoda & 112 & 35 & 3.20 & 28 & 25 & 1.12 & 2.08 & 1.47 & 5.64 & $<0.001$ \\
\hline Aranae ${ }^{\mathrm{e}}$ & 4 & 35 & 0.11 & 3 & 25 & 0.12 & -0.01 & -0.15 & -0.06 & 0.525 \\
\hline Coleoptera & 49 & 35 & 1.40 & 16 & 25 & 0.64 & 0.76 & 0.34 & 2.97 & 0.002 \\
\hline Collembola ${ }^{\mathrm{e}}$ & 143 & 35 & 4.09 & 0 & 25 & 0.00 & 4.09 & 3.52 & 11.96 & $<0.001$ \\
\hline Diptera & 789 & 35 & 22.54 & 284 & 25 & 11.36 & 11.18 & 9.46 & 10.67 & $<0.001$ \\
\hline Ephemeroptera & 74 & 35 & 2.11 & 165 & 25 & 6.60 & -4.49 & -5.42 & -7.88 & 1.000 \\
\hline Hemiptera $\mathrm{e}^{\mathrm{a}}$ & 8 & 35 & 0.23 & 1 & 25 & 0.04 & 0.19 & 0.04 & 2.09 & 0.018 \\
\hline Hirudinea $\mathrm{e}, \mathrm{f}$ & 1 & 35 & 0.03 & 6 & 25 & 0.24 & -0.21 & -0.38 & -2.07 & 0.981 \\
\hline Lepidoptera ${ }^{\mathrm{e}}$ & 2 & 35 & 0.06 & 0 & 25 & 0.00 & 0.06 & -0.01 & 1.41 & 0.079 \\
\hline Megaloptera & 5 & 35 & 0.14 & 14 & 25 & 0.56 & -0.41 & -0.68 & -2.56 & 0.995 \\
\hline Odonata & 110 & 35 & 3.14 & 38 & 25 & 1.52 & 1.62 & 0.98 & 4.18 & $<0.001$ \\
\hline Oligochaeta e,f & 5 & 35 & 0.14 & 0 & 25 & 0.00 & 0.14 & 0.04 & 2.24 & 0.013 \\
\hline Plecoptera ${ }^{\mathrm{e}}$ & 7 & 35 & 0.20 & 0 & 25 & 0.00 & 0.20 & 0.08 & 2.65 & 0.004 \\
\hline Trichoptera & 74 & 35 & 2.11 & 37 & 25 & 1.48 & 0.63 & 0.07 & 1.83 & 0.033 \\
\hline Veneroida $\mathrm{e}$ & 8 & 35 & 0.23 & 29 & 25 & 1.16 & -0.93 & -1.31 & -4.05 & 1.000 \\
\hline
\end{tabular}

${ }^{a}$ Considered used if at least one Rusty Blackbird was detected at least once during three surveys. ${ }^{b}$ Considered undetected if no Rusty Blackbirds were detected during any of the three surveys. ${ }^{\mathrm{c}}$ Rate for RUBL-detected - RUBL-undetected sites. ${ }^{\mathrm{d}}$ Significant $p$-values $(\alpha=0.05)$ are bolded. ${ }^{\mathrm{e}}$ The normal approximation may be inaccurate for small total number of occurrences. ${ }^{\mathrm{f}}$ Subclass, rather than order. 


\section{Discussion}

\subsection{Wetland Use and Aquatic Macroinvertebrate Prey}

Food availability appears to be important to breeding Rusty Blackbird wetland use in northern New England. According to our model ranking, the best predictors of Rusty Blackbird use of wetlands in northern New Hampshire and western Maine are aquatic invertebrate abundance (positively related) and percent cover of mud (negatively related). Contrary to our hypotheses, current beaver activity, presence of puddles, and conifer cover were not important factors. Our data suggest that adult Rusty Blackbirds choose foraging sites based on aquatic invertebrate prey abundance. Abundance of amphipods, beetles, true flies, dragonflies, and caddis flies were higher in sites with Rusty Blackbird detections. This is expected because young birds cannot easily digest dry seeds [30], and invertebrates contain protein needed for chicks' growing skeletons. Aquatic insects are high-quality prey items, in part because many emergents (e.g., Odonata) are soft-bodied in the teneral or subimago stage, vulnerable to capture, and easily digested.

Our model results suggest that invertebrate abundance is more important than invertebrate richness in predicting Rusty Blackbird wetland use. Given the spatial and temporal variability of beaver-influenced wetland food resources within the landscape, it makes sense that Rusty Blackbirds would choose sites with large numbers of prey items rather than sites with a diverse selection of aquatic invertebrate taxa. From 2010 to 2012, the mean distance of Rusty Blackbird nests in this area to nearest wetland was $409.65 \mathrm{~m}$ $(+/-46.15 \mathrm{SE})$ and the maximum distance was $1347 \mathrm{~m}$ [46]. Because the foraging habitat in the study area is patchy and nests can be $400 \mathrm{~m}$ or more from foraging sites [37], we would expect Rusty Blackbirds to seek out sites with abundant food resources to minimize time spent foraging and provisioning. Home ranges of 13 telemetered adult Rusty Blackbirds in Maine averaged 37.5 ha and ranged from 4-179 ha [9], suggesting that foraging strategies in this heterogeneous environment must be flexible but efficient for successfully raising chicks.

We observed Rusty Blackbirds catching and provisioning multiple prey items at once. This behavior has also been documented in a camera trap study [47] in our survey area as well as in other field observations in Maine and New Hampshire [48] and nearby Vermont [25]. Optimal Foraging Theory predicts how an animal may decide where to forage, what to forage for, and for how long to forage based on maximizing energy gained from food items while minimizing searching and handling time [49]. In addition to nesting hundreds of meters from foraging sites, Rusty Blackbirds often forage in multiple wetlands throughout their home range [9]. They may provision more food items at a time with increasing distance from the nest to the foraging site to maximize energy gained versus that expended, as has been observed in related Icterids [30]. Regional differences in breeding Rusty Blackbird foraging strategies may exist; an Alaskan study found that adult Rusty Blackbirds usually fed chicks one large ( $>2 \mathrm{~cm}$ long) prey item at a time [50]. Thus, it is possible that Rusty Blackbirds in Alaska may operate under a different foraging strategy based on finding high-quality prey rather than minimizing energy spent foraging.

Although invertebrate richness was not a strong predictor of Rusty Blackbird site use in our study, Rusty Blackbirds were more likely to use sites with higher aquatic invertebrate abundance. We modeled a total count of all aquatic invertebrates per site rather than abundance broken down by order due to small sample sizes. Because we suspected that some orders are more important than others, we conducted an exploratory analysis of Rusty Blackbird site use and invertebrate abundance by order. The total number of individual Coleopterans, Collembolans, Dipterans, and Odonates was three times as high at wetlands used by Rusty Blackbirds, four times as high for Amphipods, and twice as high for Trichopterans (Table 4). However, as noted, sites used by Rusty Blackbirds also had higher Coleoptera richness, underscoring the likely importance of aquatic beetles in the bird's diet. Although summer diet information is scarce for Rusty Blackbirds, aquatic beetles can make up 10\% or more of their diet in spring and may exceed $25 \%$ in some regions of the US [20]. 
Prey availability is not consistent over time due to differences in insect life histories, weather changes, and other factors. Rusty Blackbirds forage aerially for Odonates and other flying insects as well as hunt at the water's edge for aquatic prey. Orians [30] suggested that invertebrate prey availability is higher in warm, dry weather due to higher insect emergence rates. In 2014, the weather in our study area was generally favorable for Odonate emergence, as mean temperature was $20.8^{\circ} \mathrm{C} \pm 0.39 \mathrm{SE}$ and it rained during just $11 \%$ of surveys. Odonate emergence rates are highest during mid to late morning [30]; however, we opportunistically observed breeding Rusty Blackbirds foraging throughout the day. This observation suggests they may be choosing other prey later in the day, although we did not quantify the relative foraging time budgets for aerial, emergent, and aquatic prey. Future studies should consider using a combination of aerial and aquatic sampling methods to target different invertebrate orders and life stages.

\subsection{Wetland Characteristics}

Mud was a variable in our top wetland use model, but puddles, conifer cover, and current beaver activity were not important predictors of Rusty Blackbird wetland use. In contrast, Powell et al. found that Rusty Blackbird occupancy in New England was best explained by the presence of puddles (i.e., shallow pools of standing water), conifer cover greater than $70 \%$, and evidence of current beaver activity [41]. Although that study did not find strong support for the mud cover survey covariate, our survey methods differed; Powell et al. used a binary measure of mud presence or absence within a site [41], whereas we estimated the percent cover of mud at the wetland.

Our research indicates that Rusty Blackbirds forage in wetlands with abundant aquatic invertebrates and low percent cover of mud. Percent cover of mud is conversely related to that of open water, in which macroinvertebrates located between the water surface and the substrate are accessible to prey-seeking birds. Furthermore, the Rusty Blackbird bill ranges from 17.5 to $19 \mathrm{~mm}$ in length [51] and is not morphologically designed to probe for prey in deep mud. Rusty Blackbirds foraging in mud are likely procuring invertebrates on the surface. Studies $[52,53]$ have also suggested that wintering Rusty Blackbirds prefer sites with shallow water. In addition, Wright et al. [54] found that during migration, the birds use forest edges with leaf litter and shallow water, likely to take advantage of the proximity of both arthropods and perches.

Microhabitat features are likely important; we observed Rusty Blackbirds foraging from the surface of deep $(>1 \mathrm{~m})$ water while standing on emergent debris. A Vermont study noted that Rusty Blackbirds forage in the water from debris or logs [25]. Other studies in New England suggested an unclear relationship between shallow water extent and Rusty Blackbird occupancy [55]. Breeding Rusty Blackbirds forage in fens and wet meadows [46], yet bird use and prey communities in these shallow-water ecosystems remain understudied. Future breeding-season wetland surveys should note the presence of emergent substrates in deep standing water, as such microhabitats give Rusty Blackbirds access to otherwise inaccessible foraging areas. Additionally, future researchers should assess the heterogeneity of invertebrate food availability within each wetland, including within mud as well as around edges of emergent substrates within deeper water.

Current beaver activity in wetlands did not strongly influence wetland use by Rusty Blackbirds in our study area, as the model with wetland use as a function of beaver occupancy ranked lower than the null model. All of our study sites had been modified by beavers, which may have affected model performance. While the relationship between current beaver activity and breeding Rusty Blackbird wetland use is still unclear, beavers create both breeding and foraging habitat by increasing conifer cover and by making ponds [13], many of which persist for years to decades [56]. Furthermore, beaver-impounded streams contain greater numbers of Odonates [18], and Anisoptera nymphs prefer dams of woody debris over other habitat types [57], so beavers may increase the abundance of preferred food for breeding Rusty Blackbirds. Previous research found that the presence of current beaver activity increased the probability of Rusty Blackbird occupancy [41], which 
is expected given that beavers are associated with improved habitat for aquatic invertebrates $[58,59]$. Furthermore, aquatic invertebrate availability is likely related to water depth and vegetation cover along the wetland edge, which are factors that beavers influence indirectly, rather than to the actual presence of beavers [57]. The relationship between beaver occupancy and Rusty Blackbird wetland use is worthy of further study and refinement.

\subsection{Landscape Factors}

Glennon [60] suggested that climate change and habitat modification are the main contributors to declines of several boreal bird species including the Rusty Blackbird. Furthermore, climate change is affecting the hydrology and invertebrate communities of North American boreal wetlands [61]. Sánchez-Bayo et al. [62] noted that species in several aquatic taxa known to be prey for Rusty Blackbirds (e.g., Odonata) have declined or disappeared from many sites in North America. While we did not study insect loss or forested wetland change, the implication for the Rusty Blackbird's breeding habitat and prey base at the species' southern range limit, and perhaps across its North American summer range, is sobering. Although current beaver occupancy was not significant in the model, the influence of beavers on wetland hydrology, heterogeneity, and aquatic invertebrate assemblages is strong [58]. Land managers within the Rusty Blackbird's breeding range should, to the degree feasible, continue to manage the boreal forest landscape by allowing beaver populations to persist and include a mixture of forest stand ages in planning. It is important to allow beaver populations to continue to create impoundments in order to help invertebrate-rich wetlands persist in a changing climate [63].

\subsection{Probability of Detection}

We found that the most important predictor of detection probability for breeding Rusty Blackbirds was the visit (survey) period. As we hypothesized, the probability of detection given wetland use was highest during the second visit, when parents were rearing nestlings (28 May-10 June 2014). Rusty Blackbirds tend to be highly secretive and hard to detect during nest-building, egg-laying, and incubation. Once eggs hatch, adult Rusty Blackbirds become more vocal and more obvious as they frequently forage for food and rear their young. Soon after fledging, Rusty Blackbird broods tend to move away from their nesting areas and towards wetlands [37]. Thus, we designed our study to capture differences in breeding season behavior by surveying for Rusty Blackbirds in three survey periods that coincide with their breeding stages. To maximize breeding season detection, future studies could focus sampling effort on the chick-rearing period.

Time of day, date, wind, temperature, precipitation, and wetland size were not important predictors of Rusty Blackbird detectability. Additional factors, including vegetation cover within a wetland, noise created by running water, and anthropogenic noise, could have impacted detectability. During our study, a few sites were within earshot of logging operations, but most surveys were not noticeably impacted by anthropogenic sounds. There is also a need to compare detectability among multiple wetland types. No information exists on Rusty Blackbird occupancy of fens or wet meadows, yet the birds often forage in these shallow-water ecosystems [46]. Such information would better prepare land managers to survey areas that have not been previously studied. Lastly, although we defined a site as a wetland, our actual unit of measurement is the distance over which we were able to detect Rusty Blackbirds; however, we were unable to accurately quantify the distance at which we could hear Rusty Blackbird calls or songs at each site.

\subsection{Considerations}

Our single-season occupancy analysis provides a snapshot of Rusty Blackbird use of wetlands in New England; the study was designed to characterize differences between wetlands used by Rusty Blackbirds and wetlands that were unlikely to have hosted foraging birds. Due to limited time and resources, our study scope was defined as wetlands within $500 \mathrm{~m}$ of a road, which could have caused bias. Between-year variation in prey availability 
and habitat features were not examined in this study but are likely important, especially given changes in hydrology through time resulting from shifting beaver occupancy and precipitation patterns.

We sampled a small area (approximately $1 \mathrm{~m}^{2}$ ) for aquatic invertebrates at the edge of each wetland because the entire wetland perimeter was not accessible due to flooding or areas of downed trees. With multiple invertebrate surveys in the same marked area of each site, we were able to compare temporal changes in invertebrate food availability within a site as well as compare food availability for Rusty Blackbirds across a range of wetlands. However, because we did not sample all Rusty Blackbird prey species (such as snails and spiders) or all life stages of prey species, our surveys provide a useful but incomplete picture of each site's invertebrate community structure.

\section{Conclusions}

Our research suggests that Rusty Blackbirds forage in wetlands with abundant aquatic invertebrates and low percent cover of mud, using sites with more open water and emergent vegetation. Conservation of Rusty Blackbird populations and the diverse invertebrate communities upon which these birds depend will require land managers and biologists to explore uncharted territory. Because habitat change, mercury pollution, and climate change are regional to global issues that are difficult to address, we recommend that decision-makers within the breeding range focus on maintaining and improving nesting and foraging habitat. It is important that land managers retain existing beaver populations and manage hydrology in the face of climate change [63]. We recommend continued bird population and wetland monitoring especially because the relationships between water level and prey availability are mediated by climate and will likely experience greater variance over time. If this region becomes more drought-prone, land managers could experiment with managing wetland hydrology to support adequate soil moisture during the growing season by increasing the size of existing wetlands and creating new ones, mimicking the work of beavers.

Because much of the Canadian breeding range has not been surveyed for Rusty Blackbirds, US and Canadian researchers can collaborate to fill information gaps and identify key areas in need of protection. We recommend long-term monitoring of wetland habitat and aquatic invertebrates in the Acadian forest. Land managers, both public and private, have an exciting opportunity to help maintain and improve breeding habitats for Rusty Blackbirds and other imperiled boreal species. Conservationists should expand on education and engagement initiatives, such as the Rusty Blackbird Migration Blitz, to increase the general public's awareness of and concern for this species.

Author Contributions: Conceptualization, S.M., A.P., C.F., J.C., and S.F.; methodology, A.P., S.M., J.C. and C.F.; software, A.P. and J.C.; validation, A.P., S.M., C.F., and J.C.; formal analysis, A.P. and J.C.; investigation, A.P.; resources, S.M. and C.F.; data curation, A.P.; writing —original draft preparation, A.P. and S.M.; writing—review and editing, A.P., S.M., C.F., J.C., and S.F.; visualization, A.P. and S.M.; supervision, S.M., A.P., and C.F.; project administration, S.M. and A.P.; funding acquisition, S.M. and A.P. All authors have read and agreed to the published version of the manuscript.

Funding: This research was funded by Umbagog National Wildlife Refuge and the SUNY College of Environmental Science and Forestry Graduate Student Association Research Grant. The initial pilot study in 2013 was supported by the Northeastern States Research Cooperative through funding made available by the USDA Forest Service. The conclusions and opinions in this paper are those of the authors and not the NSRC, the Forest Service, or the USDA.

Institutional Review Board Statement: Not applicable.

Informed Consent Statement: Not applicable.

Data Availability Statement: Data presented in this study are available on request from the corresponding authors. 
Acknowledgments: Sean Flint, Ian Drew, and other US Fish and Wildlife Service personnel from Umbagog National Wildlife Refuge provided field housing, site access, and administrative support. Dan Hudnut of Wagner Forest Management, Ltd. provided site access. Devon Cote, Kelsey Schumacher, Amasa Fiske-White, and Thomas Ruland conducted surveys as field technicians. Donald Arthur processed and identified aquatic invertebrate samples. Patricia Wohner provided field research support. Luke Losada Powell provided statistical and technical support.

Conflicts of Interest: The authors declare no conflict of interest.

\section{References}

1. Niven, D.K.; Sauer, J.R.; Butcher, G.S.; Link, W.A. Christmas Bird Count provides insights into population change in land birds hat breed in the boreal forest. Am. Birds 2004, 58, 10-20.

2. Greenberg, R.; Demarest, D.W.; Matsuoka, S.M.; Mettke-Hofmann, C.; Evers, D.C.; Hamel, P.B.; Luscier, J.D.; Powell, L.L.; Shaw, D.; Avery, M.L.; et al. Understanding Declines in the Rusty Blackbird (Euphagus carolinus). In Studies in Avian Biology, Boreal Birds of North America: A Hemispheric View of Their Conservation Links and Significance; Wells, J.V., Ed.; University of California Press: Berkeley, CA, USA, 2011; pp. 107-126.

3. Greenberg, R.; Matsuoka, S.M. Rangewide ecology of the declining Rusty Blackbird: Mysteries of a species in decline. Condor 2010, 112, 770-777. [CrossRef]

4. McClure, C.J.W.; Rolek, B.W.; McDonald, K.; Hill, G.E. Climate change and the decline of a once common bird: Climate change and blackbird decline. Ecol. Evol. 2012, 2, 370-378. [CrossRef]

5. U.S. Fish and Wildlife Service Migratory Bird Program Focal Species. Available online: https://www.fws.gov/birds/ management/managed-species/focal-species.php (accessed on 9 May 2020).

6. BirdLife International. The IUCN Red List of Threatened Species, Euphagus carolinus. Available online: https://dx.doi.org/10.2 305/IUCN.UK.20182.RLTS.T22724329A131889624.en (accessed on 9 May 2020).

7. $\quad$ Edmonds, S.T.; Evers, D.C.; Cristol, D.A.; Mettke-Hofmann, C.; Powell, L.L.; McGann, A.J.; Armiger, J.W.; Lane, O.P.; Tessler, D.F.; Newell, P.; et al. Geographic and seasonal variation in mercury exposure of the declining Rusty Blackbird. Condor 2010, 112, 789-799. [CrossRef]

8. Barnard, W.H.; Mettke-Hofmann, C.; Matsuoka, S.M. Prevalence of hematozoa infections among breeding and wintering Rusty Blackbirds. Condor 2010, 112, 849-853. [CrossRef]

9. Powell, L.L.; Hodgman, T.P.; Glanz, W.E. Home ranges of Rusty Blackbirds breeding in wetlands: How much would buffers from timber harvest protect habitat? Condor 2010, 112, 834-840. [CrossRef]

10. Hamel, P.B.; Steven, D.D.; Leininger, T.; Wilson, R. Historical trends in Rusty Blackbird nonbreeding habitat in forested wetlands. In Proceedings of the Fourth International Partners in Flight Conference: Tundra to Tropics, McAllen, TX, USA, 13-16 February 2009; Rich, T.D., Arizmendi, C., Demarest, D.W., Thompson, C., Eds.; pp. 341-353.

11. Luepold, S.H.B.; Hodgman, T.P.; McNulty, S.A.; Cohen, J.; Foss, C.R. Habitat selection, nest survival, and nest predators of Rusty Blackbirds in northern New England, USA. Condor 2015, 117, 609-623. [CrossRef]

12. Rosell, F.; Bozser, O.; Collen, P.; Parker, H. Ecological impact of beavers Castor fiber and Castor canadensis and their ability to modify ecosystems. Mammal Rev. 2005, 35, 248-276. [CrossRef]

13. Müller-Schwarze, D.; Sun, L. The Beaver: Natural History of a Wetlands Engineer; Cornell University Press: Ithaca, NY, USA, 2003.

14. Johnston, C.A.; Naiman, R.K. Browse selection by beaver: Effects on riparian forest composition. Can. J. For. Res. 1990, 20, 1036-1043. [CrossRef]

15. Hood, G.A.; Larson, D.G. Ecological engineering and aquatic connectivity: A new perspective from beaver-modified wetlands. Freshw. Biol. 2015, 60, 198-208. [CrossRef]

16. Cunningham, J.M.; Calhoun, A.J.K.; Glanz, W.E. Patterns of beaver colonization and wetland change in Acadia National Park. Northeast. Nat. 2006, 13, 583-596. [CrossRef]

17. Margolis, B.E.; Raesly, R.L.; Shumwaya, D.L. The effects of beaver-created wetlands on the benthic macroinvertebrate assemblages of two Appalachian streams. Wetlands 2001, 21, 554-563. [CrossRef]

18. McDowell, D.M.; Naiman, R.J. Structure and function of a benthic invertebrate stream community as influenced by beaver (Castor canadensis). Oecologia 1986, 68, 481-489. [CrossRef]

19. Beecher, W.J. Adaptations for food-getting in the American blackbirds. Auk 1951, 68, 411-440. [CrossRef]

20. Beal, F.E.L. Food of the Bobolink, Blackbirds, and Grackles; U.S. Department Agriculture Biological Survey Bulletin, 13: Washington, DC, USA, 1900.

21. Bent, A.C. Life Histories of North American Blackbirds, Orioles, Tanagers, and Their Allies; United States National Museum Bulletin: Washinton, DC, USA, 1958; p. 211.

22. Martin, A.C.; Zim, H.S.; Nelson, A.L. American Wildlife \& Plants: A Guide to Wildlife Food Habits; Dover Publications, Inc.: New York, NY, USA, 1951; ISBN 978-0-486-20793-3.

23. Meanley, B. Blackbirds and the Southern Rice Crop; U.S. Department of the Interior, Fish and Wildlife Service: Washington, DC, USA, 1971.

24. Avery, M.L. Rusty Blackbird (Euphagus carolinus). In The Birds of North America 2000; Academy of Natural Sciences: Philadelphia, PA, USA; American Ornithologists' Union: Washington, DC, USA, 1995; p. 200. [CrossRef] 
25. Ellison, W.G. The status and habitat of the Rusty Blackbird in Caledonia and Essex Counties; Vermont Fish and Wildlife Department: Woodstock, VT, USA, 1990.

26. Cade, T.J. Aerial feeding of the Rusty Blackbird on mosquitoes. Wilson Bull. 1953, 65, 52-53.

27. Ehrlich, P.; Dobkin, D.S.; Wheye, D. Birder's Handbook; Simon and Schuster: New York, NY, USA, 1988.

28. Matsuoka, S.M.; Shaw, D.; Johnson, J.A. Estimating the abundance of nesting Rusty Blackbirds in relation to wetland habitats in Alaska. Condor 2010, 112, 825-833. [CrossRef]

29. Edmonds, S.T.; O'Driscoll, N.J.; Hillier, N.K.; Atwood, J.L.; Evers, D.C. Factors regulating the bioavailability of methylmercury to breeding rusty blackbirds in northeastern wetlands. Environ. Pollut. 2012, 171, 148-154. [CrossRef] [PubMed]

30. Orians, G.H. Blackbirds of the Americas; University of Washington Press: Seattle, WA, USA, 1985.

31. MacKenzie, D.I.; Nichols, J.D.; Lachman, G.B.; Droege, S.; Royle, J.A.; Langtimm, C.A. Estimating site occupancy when detection probabilities are less than one. Ecology 2002, 83, 2248-2255. [CrossRef]

32. U.S. Climate Data. Available online: https://www.usclimatedata.com/climate/colebrook/new-hampshire/united-states/usnh0 044 (accessed on 5 October 2020).

33. Pachomski, A.L. Foraging Habitat Characteristics, Prey Availability, and Detectability of Rusty Blackbirds: Implications for Land and Wildlife Management in the Northern Forest. Master's Thesis, State University of New York College of Environmental Science and Forestry, Syracuse, NY, USA, 2017.

34. Tavernia, B.G.; Lyons, J.E.; Loges, B.W.; Wilson, A.; Collazo, J.A.; Runge, M.C. An evaluation of rapid methods for monitoring vegetation characteristics of wetland bird habitat. Wetl. Ecol. Manag. 2015, 23, 495-505. [CrossRef]

35. Peckarsky, B.L.; Fraissinet, P.R.; Penton, M.; Conklin, D.D., Jr. Freshwater Macroinvertebrates of Northeastern North America; Cornell University Press: Ithaca, NY, USA, 1990.

36. Homer, C.G.; Dewitz, J.A.; Yang, L.; Jin, S.; Danielson, P.; Xian, G.; Coulston, J.; Herold, N.D.; Wickham, J.D.; Megown, K. Completion of the 2011 National Land Cover Database for the conterminous United States representing a decade of land cover change information. Photogramm. Eng. Remote Sens. 2015, 81, 345-354.

37. Wohner, P.J.; Foss, C.R.; Cooper, R.J. Rusty blackbird habitat selection and survivorship during nesting and post-fledging. Diversity 2020, 12, 221. [CrossRef]

38. Behnke, L.A.H.; Pejchar, L.; Crampton, L.H. Occupancy and habitat use of the endangered Akikiki and Akekee on Kauai Island, Hawaii. Condor 2016, 118, 148-158. [CrossRef]

39. Fiske, I.J.; Chandler, R.B. Unmarked: An R package for fitting hierarchical models of wildlife occurrence and abundance. J. Stat. Softw. 2011, 43, 1-23. Available online: http:/ / www.jstatsoft.org/v43/i10/ (accessed on 14 August 2016). [CrossRef]

40. R Development Core Team. R version 3.2.5: A Language and Environment for Statistical Computing; R Foundation for Statistical Computing: Vienna, Austria, 2016; Available online: http:/ / www.R-project.org (accessed on 14 August 2016).

41. Powell, L.L.; Hodgman, T.P.; Fiske, I.J.; Glanz, W.E. Habitat occupancy of Rusty Blackbirds (Euphagus carolinus) breeding in northern New England, USA. Condor 2014, 116, 122-133. [CrossRef]

42. Mazerolle, M.J. AICcmodavg: Model Selection and Multimodel Inference Based on (Q)AIC(c). R Package Version 2.0-4. 2016. Available online: http:/ / CRAN.R-project.org/package=AICcmodavg (accessed on 14 August 2016).

43. MacKenzie, D.I.; Bailey, L.L. Assessing the fit of site-occupancy models. J. Agric. Biol. Environ. Stat. 2004, 9, 300-318. [CrossRef]

44. Lebreton, J.D.; Burnham, K.P.; Clobert, J.; Anderson, D.R. Modeling survival and testing biological hypotheses using marked animals: A unified approach with case studies. Ecol. Monogr. 1992, 62, 67-118. [CrossRef]

45. Burnham, K.P.; Anderson, D.R. Model Selection and Multimodel Inference: A Practical Information-Theoretic Approach, 2nd ed.; Springer-Verlag: New York, NY, USA, 2002.

46. Foss, C.; Wohner, P.J. Rusty Blackbird Nest Locations in Relation to Wetlands. Unpublished.

47. Buckley, S.H. Rusty Blackbirds in Northeastern U.S. Industrial Forests: A Multi-Scale Study of Nest Habitat Selection and Nest Survival. Master's Thesis, State University of New York College of Environmental Science and Forestry, Syracuse, NY, USA, 2013.

48. Foss, C. (New Hampshire Audubon, Concord, NH, USA). Personal communication, 2017.

49. Sinervo, B. Chapter 6: Optimal Foraging Theory: Constraints and Cognitive Processes. In Behavioral Ecology; University of California: Santa Cruz, CA, USA, 1997.

50. Loomis, D. Reproductive Success and Foraging Ecology of the Rusty Blackbird on the Copper River Delta, Alaska. Master's Thesis, Oregon State University, Corvallis, OR, USA, 2013.

51. Meanley, B. Aging and Sexing Blackbirds, Bobolinks, and Starlings; U.S. Fish Wildlife Service, Patuxent Wildlife Research Center: Laurel, MD, USA, 1967.

52. Borchert, S.M. Site-Specific Habitat and Landscape Associations of Rusty Blackbirds Wintering in Louisiana. Master's Thesis, Louisiana State University, Baton Rouge, LA, USA, 2015.

53. DeLeon, E.E. Ecology of Rusty Blackbirds Wintering in Louisiana: Seasonal Trends, Flock Composition, and Habitat Associations. Master's Thesis, Louisiana State University, Baton Rouge, LA, USA, 2012.

54. Wright, J.R.; Powell, L.L.; Matthews, S.N.; Tonra, C.M. Rusty blackbirds select areas of greater habitat complexity during stopover. Condor 2020, 122, 1-18. [CrossRef]

55. Scarl, J.C. Rusty Blackbirds 2012: Building Connections for a Declining Species; Vermont Center for Ecostudies: Norwich, VT, USA, 2013.

56. Naiman, R.J.; Johnston, C.A.; Kelley, J.C. Alteration of North American streams by beaver. BioScience 1988, 38, 753-762. [CrossRef] 
57. Burcher, C.; Smock, L. Habitat distribution, dietary composition and life history characteristics of odonate nymphs in a blackwater coastal plain stream. Am. Midl. Nat. 2002, 148, 75-89. [CrossRef]

58. Hood, G.A.; Larson, D.G. Beaver-created habitat heterogeneity influences aquatic invertebrate assemblages in boreal Canada. Wetlands 2014, 34, 19-29. [CrossRef]

59. Bush, B.M.; Stenert, C.; Maltchik, L.; Batzer, D.P. Beaver-created successional gradients increase $\beta$-diversity of invertebrates by turnover in stream-wetland complexes. Freshw. Biol. 2019, 64, 1265-1274. [CrossRef]

60. Glennon, M. Analysis of Boreal Bird Trends in the Adirondack Park, 2007-2016: Report to the New York State Department of Environmental Conservation; Wildlife Conservation Society: Saranac Lake, NY, USA, 2017.

61. Corcoran, R.M.; Lovvorn, J.R.; Heglund, P.J. Long-term change in limnology and invertebrates in Alaskan boreal wetlands Hydrobiologia 2009, 620, 77-89. [CrossRef]

62. Sánchez-Bayo, F.; Wyckhuys, K.A.G. Worldwide decline of the entomofauna: A review of its drivers. Biol. Conserv. 2019, 232, 8-27. [CrossRef]

63. Hood, G.A.; Bayley, S.E. Beaver (Castor canadensis) mitigate the effects of climate on the area of open water in boreal wetlands in western Canada. Biol. Conserv. 2008, 141, 556-557. [CrossRef] 